\title{
Urgensi Psikologi Islam Dalam Pendidikan Islam
}

\author{
Mubarak $^{1}$ \\ Universitas Islam Negeri (UIN) Antasari, Banjarmasin
}

\begin{abstract}
This paper examines the urgency of Islamic Psychology in Islamic Education. Education and psychology cannot be separated, both have a very close relationship. Education is a long process to actualize all the potential of human self so that the potential of humanity to be actual. In terms of Islamic education is needed is Islamic Psychology, because humans have the potential of noble, namely fitrah and spirit that is not touchable in general psychology (West). Islamic education should have a psychological foundation that is insightful to Islam, in this case with a guide to the Qur'an and Hadith as its source, so that the end of the goal of Islamic education can be realized and create a plenary human (insan kamil).

Islamic education psychology devotes attention to the behavior or behavior of those who engage in learning and teaching activities or those directly involved in the learning process. Islamic education psychology has two objects, namely: First, learners, ie individuals (individuals) who are learning, including approaches, strategies, influencing factors and achievements achieved. Secondly, teachers (educators), those who are obliged or undertake teaching responsibilities, including methods, models, strategies, and others related to the activity of presenting Islamic education. Islamic education based on Islamic Psychology will produce human beings who have a potential base that is a qualified potential of physical, spiritual, and fitrah or better known as jismiah, nafsiah and ruhaniah.
\end{abstract}

Kata Kunci: Psikologi Islam; Pendidikan Islam

\section{Pendahuluan}

Pendidikan dan psikologi tidak dapat dipisahkan, keduanya memiliki hubungan yang sangat erat. Pendidikan merupakan suatu proses panjang untuk mengaktualkan seluruh potensi diri manusia sehingga potensi kemanusiaannya menjadi aktual. Dalam proses mengaktualisasi diri tersebut diperlukan pengetahuan tentang keberadaan potensi, situasi dan kondisi lingkungan yang tepat untuk mengaktualisasikannya. Pengetahuan tentang diri manusia dengan segenap permasalahannya akan dibicarakan dalam psikologi.

M. Quraish mengutip pendapat Dr. A. Carel dalam bukunya Man the Unknown menjelaskan bahwa pengetahuan manusia tentang dirinya sangat terbatas, hal itu disebabkan oleh: pertama, pada mulanya perhatian manusia tertuju pada penyelidikan

\footnotetext{
${ }^{1}$ Korespondensi untuk tulisan ini ditujukan kepada email mubarak6339@gmail.com
} 
tentang materi dan terlambat melakukan penelitian tentang diri manusia. Pada zaman primitif, nenek moyang kita disibukkan untuk menjinakkan dan menundukkan alam sekitarnya, seperti upaya membuat senjata untuk mempertahankan diri dan melawan binatang-binatang buas, penemuan api, pertanian, peternakan dan sebagainya, sehingga mereka tidak menyempatkan waktu untuk memikirkan tentang dirinya. Begitupun halnya pada masa renaisans (zaman pembaharuan), para ahli di era itu hanya disibukkan untuk melakukan penelitian dan penemuan-penemuan baru yang berorientasi profit material dan menyenangkan publik, karena hal-hal yang baru tersebut mempermudah kehidupan mereka. Kedua, sifat akal kita tidak mampu mengetahui hakikat hidup, karena ciri khas akal manusia kecenderungannya memikirkan hal-hal yang sederhana dan tidak rumit. Ketiga, kehidupan perilaku manusia sangat komplek, tidak hanya didekati lewat penelitianpenelitian yang nampak saja, hanya dipengaruhi oleh faktor fisik-biologis, psiko-edukasi, maupun sosio-kultur, tetapi ada dimensi lain sebagai sumber kehidupan manusia, yaitu dimensi spiritual, yang akhir-akhir diakui oleh dunia psikologi modern. ${ }^{2}$

Frankl mengenalkan corak pandangan psikologinya ini dengan istilah neotic. Neotic sering disebut dimensi keruhanian (spiritual). Menurutnya pengertian ruhani di sini sama sekali tidak mengandung konotasi agamis, tetapi dimensi ini dianggap sebagai inti kemanusiaan dan merupakan sumber makna hidup, potensi dari berbagai kemampuan dan sifat luhur manusia yang luar biasa yang sejauh ini terabaikan dari telaah psikologi sebelumnya. Logoterapi mengajarkan bahwa manusia harus dipandang sebagai kesatuan fisik-psikis-ruhani yang tak terpisahkan. ${ }^{3}$ Teori ini juga menganggap bahwa hasrat untuk hidup bermakna adalah motivasi utama manusia. Islam semenjak awal telah menjelaskan bahwa manusia adalah satu-satunya makhluk yang dalam unsur penciptaannya terdapat ruh Ilahi. Demikian yang tersirat dalam al-Qur'an surat Al-Isra ayat 85.

Apabila yang dikemukakan Viktor Frankl dan A. Carrel itu diterima, maka jalan untuk mengenal dan menemukan jawaban tentang hakikat manusia adalah merujuk kepada wahyu Ilahi. Usaha tersebut tentu tidak cukup hanya dengan mengambil satu atau dua ayat, tetapi seharusnya merujuk pada semua ayat Alquran atau paling tidak ayat-ayat pokok

\footnotetext{
${ }^{2}$ M Qurais Shihab, Wawasan Al-Qur'an: Tafsir Maudhu'i Atas Pelbagai Persoalan Umat (Bandung: Mizan, 1996). 45

${ }^{3}$ Muhibbin Syah, Psikologi Psikologi Pendidikan Dengan Pendekatan Baru (Bandung: Remaja Rosdakarya, 2003). 76
} 
yang berbicara tentang masalah yang dibahas, dengan mempelajari konteksnya masingmasing, dan diperkuat dengan penjelasan sunnah Rasul maupun penemuan-penemuan ilmiah yang telah mapan. Cara ini dalam disiplin ilmu Alquran dikenal dengan metode tematis maudhu'i.

Kajian psikologi berdasarkan Islam menjadi penting karena dalam prakteknya banyak disiplin keilmuan Islam yang mendasarkan pada teori psikologi. Dalam kajian pendidikan Islam misalnya, selama ini merujuk pada teori dan konsep psikologi perkembangan dan psikologi belajar dari psikologi konvensional (Barat). Sudah seharusnya teori-teori psikologi pendidikan Islam didasarkan pada Psikologi Islam, karena terdapat perbedaan fundamental di antara keduanya. Di sinilah di antaranya, peran penting Psikologi Islam.

\section{Hasil dan Diskusi}

\section{Pengertian Psikologi}

Psikologi merupakan ilmu terapan yang mempelajari perilaku manusia dan fungsi mental ilmiah. Psikologi mencoba untuk mempelajari peran fungsi mental dalam perilaku individu dan kelompok, serta belajar tentang proses fisiologis dan neurobiologis yang mendasari perilaku. ${ }^{4}$

Kata psikologi berasal dari bahasa Yunani yang terdiri dari "psyche" yang berarti "jiwa" dan "logos" yang berarti "ilmu". Adapun perbedaan ilmu jiwa dan psikologi adalah ilmu jiwa merupakan istilah Bahasa Indonesia sehari-hari yang dikenal umum yang meliputi segala pemikiran, pengetahuan, tanggapan, khayalan, dan spekulasi mengenai jiwa. Sedangkan psikologi merupakan istilah ilmu pengetahuan yang diperoleh dengan sistematis melalui metode-metode ilmiah yang mengandung beberapa syarat yang telah dimufakati oleh para sarjana psikologi. Dengan kata lain Ilmu jiwa belum tentu psikologi, tetapi psikologi sudah pasti ilmu jiwa.

Psikologi menjadi ilmu pengetahuan mandiri karena telah memenuhi syarat sebagai ilmu yaitu memiliki obyek yang dapat diobservasi, memiliki metode ilmiah, dan tersusun secara sistematis. Obyek yang dipelajari psikologi adalah perilaku (kognitif, afektif, maupun psikomotorik) dan proses-proses mental manusia lainnya.

\footnotetext{
${ }^{4}$ Bimo Walgito, Psikologi Sosial (Suatu Pengantar) (Yogyakarta: Andi Offset, 2000). 10
} 


\section{Menuju Psikologi Islam}

Empat aliran psikologi yang sudah berdiri saat ini adalah psikoanalisis, behavioristik, humanistik dan transpersonal.Keempat pendekatan ini belum mampu menjawab secara integral tentang karakteristik dan esensi perilaku manusia.Maka disepakati bahwa salah satu visi psikologi Islam adalah sebagai mazhab kelima, menjadi aliran yang independen, yang diharapkan mampu menjawab tantangan tersebut dan memililki pandanganpandangan yang khas.

Protes kalangan Islam terhadap konsep Psikologi Barat terutama terletak pada nilai spiritualitas yang sama sekali tidak menjadi dasar dan konsep dari Psikologi konvensional (Barat) tersebut. Hal ini dipandang tidak sesuai dengan nilai-nilai Islam. Para pakar Psikologi dari kalangan umat Islam kemudian berusaha untuk merumuskan konsep mengenai Psikologi Islam atau Islami.

Psikologi konvensional berpandangan bahwa perilaku kehidupan manusia sangat dipengaruhi oleh tridimensi: dimensi fisik-biologis, psiko-edukasi, dan sosio-kultural, sedang dimensi spiritual tidak mendapatkan tempat dalam ruang kehidupan manusia. Dapat dikatakan bahwa hanya dengan menggunakan kemampuan intelektual semata dapat ditemukan dan diungkapkan asas-asas kejiwaan.

Psikologi (barat) berasumsi bahwa alam semesta secara keseluruhan bersifat materi, tanpa makna dan tujuan. Menurut Psikologi barat, manusia tidak lebih dari organisme tubuh, pikiran manusia berkembang berasal dari sistem syaraf tubuh semata dan tidak mengakui adanya dimensi spiritual. Berbeda dengan psikologi Islam, menurutnya alam semesta diciptakan berdasarkan kehendak Tuhan, dan mencerminkan eksistensi-Nya. Allah berkata dalam quran surah al-Baqarah ayat 115: "bahwa milik Allah-lah Timur dan Barat, kemanapun kamu menghadap, di situlah wajah Tuhan berada".

Psikologi Islam mendekatinya dengan memfungsikan akal dan keimanan, yakni dengan cara mengoptimalkan daya nalar yang obyektif-ilmiah dengan metodenya yang tepat. Psikologi Islam mencoba memahami manusia dalam kerangka Islam. Pada dasarnya upaya yang dilakukan untuk mengembangkan psikologi yang bermuatan nilai-nilai keislaman yang didasarkan pada tiga asumsi: pertama, para ahli mensinyalir bahwa abad ini adalah zamannya kecemasan (anxiety) dan kegelisahan (restlessness). Dunia mengalami krisis moral dan kepercayaan, sehingga kondisi kejiwaan seseorang mulai membutuhkan suasana 
yang menyejukkan. Salah satu solusi yang dipandang cukup signifikan dalam menyelesaikan problem kejiwaan tersebut adalah dengan menghadirkan diskursus Psikologi. Kedua, Psikologi kontemporer sekuler yang hanya semata-mata menggunakan kemampuan intelektual belum mampu memecahkan problem kejiwaan manusia, dan memang sesuai dengan cirinya yang netral-etik-antrophosentris, Psikologi ini memaksakan diri hanya pada pendekatan empiris. Akibatnya, psikologi tercerabut dari akar pengertiannya yang semula bermaksud membahas tentang jiwa manusia dialihkan pada pembahasan "gejala jiwa". Perubahan ini memunculkan kritik terhadap keberadaan Psikologi, yang didefinisikan sebagai “ilmu jiwa yang tidak mempelajari jiwa, atau ilmu jiwa yang mempelajari manusia tidak berjiwa".

Pengertian model Psikologi seperti ini mengakibatkan distorsi fungsi hakikat psikologi. Agar Psikologi tetap pada fungsinya, diperlukan pendekatan baru dalam pengembangannya.Salah satunya adalah dengan menghadirkan nilai-nilai Islam. Hal ini ternyata banyak menginspirasi para ilmuan Barat akan kebekuan dan kekeringan teori-teori Barat dalam menganalisa kejiwaan manusia, sehingga memunculkan teori-teori baru dan menggulirkan mazhab baru dalam perkembangan psikologi yang dimulai dengan penemuan Viktor Frankl dengan "logoterapi"-nya. Teori ini meretas jalan berdirinya satu aliran baru yang menjadi tren wacana psikologi di dunia Barat kini (khususnya Amerika), yaitu "psikologi Transpersonal".Diakui atau tidak pendekatan ini diilhami oleh dunia sufisme yang berakar kuat dari sumber Islam. ${ }^{5}$

\section{Pengertian Pendidikan}

Kata "pendidikan" berdasarkan KBBI berasal dari kata 'didik' dan kemudian mendapat imbuhan 'pe' dan akhiran 'an', maka kata ini mempunyai arti proses atau cara atau perbuatan mendidik.Kata "pendidikan" juga berasal dari bahasa Yunani kuno yaitu dari kata "Pedagogi" kata dasarnya Paid yang berarti "anak" dan juga kata Ogogos artinya "membimbing". Dari beberapa kata tersebut maka kita simpulkan kata pedagos dalam bahasa Yunani adalah ilmu yang mempelajari tentang seni mendidik anak.

\footnotetext{
${ }^{5}$ Hannna Djumhana Bastaman, Integrasi Psikologi Dengan Islam Menuju Psikologi Islami (Yogyakarta: Pustaka Pelajar, 1997). 53
} 
Secara bahasa definisi pendidikan adalah proses pengubahan sikap dan tata laku seseorang atau kelompok dalam usaha mendewasakan manusia melalui upaya pengajaran dan pelatihan yang sesuai prosedur pendidikan itu sendiri. Menurut UU No. 20 tahun 2003 pengertian pendidikan adalah sebuah usaha yang dilakukan secara sadar dan terencana untuk mewujudkan suasana belajar dan proses pembelajaran agar peserta didik secara aktif mengembangkan potensi dirinya untuk memiliki kekuatan spiritual keagamaaan, membangun kepribadian, pengendalian diri, kecerdasan, akhlak mulia, serta keterampilan yang diperlukan dirinya, masyarakat, bangsa, dan negara. Undang-undang inilah yang menjadi dasar berdirinya proses pendidikan yang ada di Negara Indonesia.

Pengertian pendidikan menurut Bapak Pendidikan Nasional Indonesia Ki Hajar Dewantara adalah sebagai berikut:

“Pendidikan yaitu tuntutan di dalam hidup tumbuhnya anak-anak, adapun maksudnya, pendidikan yaitu menuntun segala kekuatan kodrat yang ada pada anakanak itu, agar mereka sebagai manusia dan sebagai anggota masyarakat dapatlah mencapai keselamatan dan kebahagiaan setinggi-tingginya". ${ }^{6}$

Berdasarkan pengertian-pengertian di atas maka dapat kita pahami bahwa pendidikan adalah proses melakukan bimbingan, pembinaan atau pertolongan yang diberikan oleh orang dewasa kepada perkembangan anak untuk mencapai kedewasaannya dengan tujuan agar anak cukup mampu untuk melaksanakan tugas hidupnya sendiri secara mandiri tidak terlalu bergantung terhadap bantuan dari orang lain.

\section{Pendidikan Islam}

Pendidikan dalam Islam lebih banyak dikenal dengan menggunakan istilah al-tarbiyah, al-ta'lim, al-ta'dib dan al-riyadah." Setiap terminologi tersebut mempunyai makna yang berbeda satu sama lain, karena perbedaan teks dan kontek kalimatnya.

Pendidikan Islam adalah usaha maksimal untuk menentukan kepribadian anak didik berdasarkan ketentuan-ketentuan yang telah digariskan dalam Alquran dan Sunnah. Usaha tersebut senantiasa harus dilakukan melalui bimbingan, asuhan dan didikan, dan sekaligus pengembangan potensi manusia untuk meningkatkan kualitas intelektual dan moral yang berpedoman pada syariat Islam

\footnotetext{
${ }^{6}$ Ahmad D. Marimba, Pengantar Filsafat Pendidikan Islam (Bandung: PT. Al-Ma'arif, n.d.). 20
} 


\section{Aktualisasi Psikologi Islam dalam Pendidikan Islam}

Manusia merupakan makhluk pilihan Allah yang mengembangkan tugas ganda, yaitu sebagai khalifah Allah dan abdullah (Abdi Allah).Untuk mengaktualisasikan kedua tugas tersebut, manusia dibekali dengan sejumlah potensi didalam dirinya. Hasan Langgulung mengatakan, potensi-potensi tersebut berupa ruh, nafs, akal, qalb, dan fitrah. ${ }^{7}$ Sejalan dengan itu, Zakiyah Darajat mengatakan, bahwa potensi dasar tersebut berupa jasmani, rohani, dan fitrah namun ada juga yang menyebutnya dengan jismiah, nafsiah dan ruhaniah. ${ }^{8}$

1. Aspek jismiah

Aspek jismiah adalah keseluruhan organ fisik-biologis, serta sistem sel, syaraf dan kelenjar diri manusia.Organ fisik manusia adalah organ yang paling sempurna diantara semua makhluk. Alam fisik-material manusia tersusun dari unsur tanah, air, api dan udara. Keempat unsur tersebut adalah materi dasar yang mati.Kehidupannya tergantung kepada susunan dan mendapat energi kehidupan yang disebut dengan nyawa atau daya kehidupan yang merupakan vitalitas fisik manusia. Kemampuannya sangat tergantung kepada sistem konstruksi susunan fisik-biologis, seperti: susunan sel, kelenjar, alat pencernaan, susunan saraf sentral, urat, darah, tulang, jantung, hati dan lain sebagainya. ${ }^{9}$ Jadi, aspek jismiah memiliki dua sifat dasar yakni berupa bentuk konkrit berupa tubuh kasar yang tampak dan bentuk abstrak berupa nyawa halus yang menjadi sarana kehidupan tubuh. Aspek abstrak jismiah inilah yang akan mampu berinteraksi dengan aspek nafsiah dan ruhaniah manusia.

\section{Aspek Nafsiah}

Aspek nafsiah adalah keseluruhan kualitas insaniah yang khas dimiliki dari manusia berupa pikiran, perasaan dan kemauan serta kebebasan.Dalam aspek nafsiah ini terdapat tiga dimensi psikis, yaitu dimensi nafsu, 'aql, dan qalb.

a. Dimensi nafsu merupakan dimensi yang memiliki sifat-sifat kebinatangan dalam sistem psikis manusia, namun dapat diarahkan kepada kemanusiaan setelah mendapatkan pengaruh dari dimensi lainnya, seperti 'aql dan qalb, ruh dan fitrah. Nafsu adalah dayadaya psikis yang memiliki dua kekuatan ganda, yaitu: daya yang bertujuan untuk menghindarkan diri dari segala yang membahayakan dan mencelakakan (daya al-

\footnotetext{
${ }^{7}$ Hasan Langgulung, Manusia Dan Pendidikan; Suatu Analisa Psikologi, Falsafah Dan Pendidikan (Jakarta: Pustaka al Husna., 1986). 10

${ }^{8}$ Zakiah Daradjat, Ilmu Pendidikan Islam (Jakarta: Bumi Aksara, 2006). 57

${ }^{9}$ Ibid. 58
} 
ghadabiyah) serta daya yang berpotensi untuk mengejar segala yang menyenangkan (daya al-syahwaniyyah).

b. Dimensi akal adalah dimensi psikis manusia yang berada diantara dua dimensi lainnya yang saling berbeda dan berlawanan, yaitu dimensi nafsu dan qalb. Nafsu memiliki sifat kebinatangan dan qalb memiliki sifat dasar kemanusiaan dan berdaya cita-rasa. Akal menjadi perantara diantara keduanya. Dimensi ini memiliki peranan penting berupa fungsi pikiran yang merupakan kualitas insaniah pada diri manusia.

c. Dimensi qalb memiliki fungsi kognisi yang menimbulkan daya cipta seperti berpikir, memahami, mengetahui, memperhatikan, mengingat dan melupakan. Fungsi emosi yang menimbulkan daya rasa seperti tenang, sayang dan fungsi konasi yang menimbulkan daya karsa seperti berusaha. ${ }^{10}$

d. Aspek ruhaniah

Aspek ruhiyah adalah keseluruhan potensi luhur (high potention) diri manusia.Potensi luhur itu memancar dari dimensi ruh dan fitrah.Kedua dimensi ini merupakan potensi diri manusia yang bersumber dari Allah.Aspek ruhaniyah bersifat spiritual dan transedental. Spiritual, karena ia merupakan potensi luhur batin manusia yang merupakan sifat dasar dalam diri manusia yang berasal dari ruh ciptaan Allah. ${ }^{11}$ Bersifat transendental, karena mengatur hubungan manusia dengan yang Maha transenden yaitu Allah.Fungsi ini muncul dari dimensi fitrah.

Dari penjabaran tersebut, dapat disebutkan bahwa aspek jismiah bersifat empiris, konkrit, indrawi, mekanistik dan determenistik.Aspek ruhaniah bersifat spiritual, transeden, suci, bebas, tidak terikat pada hukum dan prinsip alam dan cenderung kepada kebaikan.Aspek nafsiah berada diantara keduanya dan berusaha mewadahi kepentingan yang berbeda.

Pada hakikatnya, proses pendidikan merupakan proses aktualisasi potensi diri manusia. Sistem proses menumbuhkembangkan potensi diri itu telah ditawarkan secara sempurna dalam sistem ajaran Islam, ini yang pada akhirnya menyebabkan manusia dapat menjalankan tugas yang telah dibebankan Allah.

\footnotetext{
${ }^{10}$ Ibid. 60

${ }^{11}$ Ibid. 67
} 
Landasan pendidikan diperlukan dalam dunia pendidikan khususnya di negara kita Indonesia, agar pendidikan yang sedang berlangsung di negara kita ini mempunyai pondasi atau pijakan yang sangat kuat karena pendidikan di setiap negara tidak sama.

Psikologi merupakan salah satu landasan penting yang harus dipertimbangkan dalam dunia pendidikan kita khususnya dalam kegiatan pengembangan kurikulum sekolah. Pengembangan kurikulum harus memperhatikan tingkat perkembangan Psikologi peserta didik. Hal ini perlu dilakukan agar materi dan tujuan yang ingin dicapai sesuai dengan kemampuan peserta didik.Jangan sampai pemberian materi kepada peserta didik tidak sesuai dengan tingkat perkembangan psikologinya, misalnya materi yang semestinya diberikan kepada peserta didik di SMA, ternyata diberikan di SD. Pendidikan memang tidak bisa dilepaskan dari psikologi. Sumbangsih psikologi terhadap pendidikan sangatlah besar.Kegiatan pendidikan, khususnya pada pendidikan formal, seperti pengembangan kurikulum, proses belajar mengajar, sistem evaluasi, dan layanan bimbingan dan konseling merupakan beberapa kegiatan utama dalam pendidikan yang di dalamnya tidak bisa dilepaskan dari Psikologi.

Psikologi yang diterapkan dalam dunia pendidikan dinamakan psikologi pendidikan dimana menurut Crow and Crow merupakan suatu ilmu yang berusaha menjelaskan masalah belajar yang dialami individu dari sejak lahir sampai usia lanjut yang menyangkut keadaan fisik, sosial, mental, minat, sikap, sifat kepribadian dan lain-lain.12

Pendidikan sebagai suatu kegiatan yang di dalamnya melibatkan banyak orang, diantaranya peserta didik, pendidik, administrator, masyarakat dan orang tua peserta didik. Oleh karena itu, agar tujuan pendidikan dapat tercapai secara efektif dan efisien, maka setiap orang yang terlibat dalam pendidikan tersebut seyogyanya dapat memahami tentang perilaku individu sekaligus dapat menunjukkan perilakunya secara efektif.

Pendidikan Islam bertujuan untuk mewujudkan manusia yang berkepribadian muslim baik secara lahir maupun batin, mampu mengabdikan segala amal perbuatannya untuk mencari keridhaan Allah Swt. Dengan demikian, hakikat cita-cita pendidikan Islam adalah melahirkan manusia-manusia yang beriman dan berilmu pengetahuan, satu sama lain saling menunjang. Dalam hal pendidikan Islam ini yang dibutuhkan adalah Psikologi

\footnotetext{
${ }^{12}$ Crow and Crow, Educational Psikology (America: Barner and Noble Books, 1978). 224
} 
Islam, karena manusia memiliki potensi luhur, yaitu fitrah dan ruh yang tidak terjamah dalam psikologi umum (Barat).

\section{Implikasi Psikologi terhadap Konsep Pendidikan}

Tinjauan psikologi perkembangan, psikologi belajar dan psikologi sosial memberikan implikasi kepada konsep pendidikan.Implikasi itu sebagian besar dalam bidang kurikulum. I Made Pidarta ${ }^{13}$ menyebutkan implikasi tersebut sebagai berikut:

1. Psikologi perkembangan yang bersifat umum, yang berorientasi pada kognisi, afeksi, dan psikomotor memberi petunjuk pada pendidik untuk menyiapkan dan mengorganisasikan materi pendidikan serta bagaimana dapat membina dan mengembangkan kemampuan anak secara optimal.

2. Psikologi belajar berimplikasi pada proses pembelajaran. Teori belajar klasik masih sering digunakan walaupun umumnya sudah lama. Teori belajar disiplin mental bermanfaat untuk menghafal dan melatih soal-soal. Teori behaviorisme lebih cocok untuk membentuk perilaku nyata, seperti mau menyumbang, giat bekerja dan lain sebagainya, sedangkan teori Kognitifisme untuk mempelajari pelajaran yang lebih rumit yang membutuhkan pemahaman, untuk memecahkan masalah dan berkreasi menciptakan bentuk ide baru.

3. Psikologi sosial

a. Konsep tentang diri sendiri atau persepsi diri bersumber dari persepsi kita tentang lingkungan dan banyak dipengaruhi oleh sikap serta perasaan kita sehingga pendidik diharapkan dapat mengembangkan sikap serta perasaan yang positif karena konsep diri yang keliru dapat merusak perkembangan anak.

b. Pembentukan sikap bisa secara alami, dikondisi dan meniru sikap para tokoh. Pendidik perlu membentuk sikap anak yang positif dalam banyak hal dengan cara merencanakan dan melaksanakannya dalam waktu dan situasi yang tepat. Dan juga perlu dikembangkan motivasinya dengan cara memenuhi minat dan kebutuhannya, memberikan tugas-tugas yang menantang dan menanamkan harapan-harapan yang sukses.

${ }^{13}$ Nur Ulwiyah, "LANDASAN PSIKOLOGI DAN AKTUALISASINYA DALAM PENDIDIKAN ISLAM," Religi: Jurnal Studi Islam 6, no. 1 (2015): 76-99. 
c. Pendidik perlu membendung perilaku agresif anti sosial, tetapi mengembangkan agresif prososial dan sanksi dengan cara menerapkan ketertiban dan kedisiplinan dan berupaya agar anak tidak mengalami rasa putus asa. Dan hubungannnya dengan kelompok kemampuan memimpin anak perlu dikembangkan karena kepemimpinan sangat besar peranannya dalam mencapai sukses belajar bersama, sukses berorganisasi yang dapat dijadikan bekal kelak jika sudah dewasa.

Psikologi pendidikan adalah sebuah disiplin psikologi yang menyelidiki masalah psikologis yang terjadi dalam dunia pendidikan. Sedangkan menurut ensiklopedia amerika, pengertian psikologi pendidikan adalah ilmu yang lebih berprinsip dalam proses pengajaran yang terlibat dengan penemuan-penemuan dan menerapkan prinsip-prinsip dan cara untuk meningkatkan keefisien di dalam pendidikan. ${ }^{14}$

Objek kajian psikologi pendidikan tanpa mengabaikan persoalan psikologi guru terletak pada peserta didik.Karena hakikat pendidikan adalah pelayanan khusus diperuntukkan bagi peserta didik. Oleh karena itu objek kajian psikologi pendidikan, selain teori-teori psikologi pendidikan sebagai ilmu, tetapi lebih condong pada aspek psikologis peserta didik, khususnya ketika mereka terlibat dalam proses pembelajaran.

Menurut Glover dan Ronning bahwa objek kajian psikologi pendidikan mencakup topik-topik tentang pertumbuhan dan perkembangan peserta didik, hereditas dan lingkungan, perbedaan individual peserta didik, potensi dan karakteristik tingkah laku peserta didik, pengukuran proses dan hasil pendidikan dan pembelajaran, kesehatan mental, motivasi dan minat, serta disiplin lain yang relevan. ${ }^{15}$

Tujuan pendidikan Islam, sebagaimana dijelaskan Jalaluddin ${ }^{16}$ adalah sejalan dengan tujuan ajaran Islam yaitu membentuk akhlak yang mulia dalam kaitannya dengan hakikat penciptaan manusia.Athiyah al-Abrasyi mengatakan bahwa tujuan pendidikan Islam adalah budi pekerti.Dijelaskan bahwa budi pekerti adalah jiwa dari pendidikan Islam. Sementara lebih luas lagi, Al-Ghazali mengatakan bahwa tujuan pendidikan Islam adalah menuju kesempurnaan manusia yang tujuannya adalah mencapai kebahagiaan dunia dan akhirat. ${ }^{17}$

\footnotetext{
${ }^{14}$ Muhibbin Syah, Psikologi Psikologi Pendidikan Dengan Pendekatan Baru. 7

${ }^{15}$ Danim and Khairil, Psikologi Pendidikan Dalam Perspektif Baru (Bandung: Alfabeta, 2010). 13

${ }^{16}$ Jalaluddin Rakhmat, Psikologi Agama, Sebuah Pengantar (Bandung: Mizan, 2003). 182

${ }^{17}$ Ibid. 183
} 
Memperhatikan berbagai tujuan pendidikan Islam yang disampaikan tersebut, maka pendidikan Islam, sebagaimana juga konsep pendidikan secara umum, seluruhnya menempatkan aspek mental, jiwa dan spiritual sebagai bagian penting dalam pendidikan. Kesempurnaan manusia untuk mencapai kebahagiaan dunia dan akhirat menguatkan posisi aspek psikologi dalam pendidikan.

Psikologi pendidikan Islam dapat dipahami sebagai suatu ilmu pengetahuan yang mengkaji atau mempelajari tingkahlaku individu, di dalam usaha mengubah tingkahlakunya yang dilandasi oleh nilai-nilai ajaran Islam dalam kehidupan pribadinya atau kehidupan kemasyarakatannya dan kehidupan dalam alam sekitar melalui proses pendidikan.

Psikologi pendidikan Islam mencurahkan perhatian pada perilaku ataupun tindak tanduk orang-orang yang melakukan kegiatan belajar dan mengajar atau orang yang terlibat langsung dalam proses pembelajaran. Psikologi pendidikan Islam mempunyai dua objek, yaitu: Pertama, Peserta didik, yaitu orang-orang (individu) yang sedang belajar, termasuk pendekatan, strategi, faktor mempengaruhi dan prestasi yang dicapai. Kedua, guru (pendidik), yaitu orang-orang yang berkewajiban atau melakukan tanggung jawab mengajar, termasuk metode, model, strategi, dan lain-lain yang berkaitan dengan aktivitas penyajian pendidikan Islam. ${ }^{18}$

Menurut Nana Syaodih Sukmadinata, minimal ada dua bidang psikologi yang mendasari pengembangan kurikulum, yaitu psikologi perkembangan dan psikologi belajar. Keduanya sangat diperlukan, baik dalam merumuskan tujuan, memilih dan menyusun bahan ajar, memilih dan menetapkan metode pembelajaran serta tekni-teknik penilaian. ${ }^{19}$

Dari sini dilihat urgensi pendidikan Islam dan psikologi. Dalam kajian psikologi pendidikan selama ini, dasar-dasar psikologi yang dijadikan landasan tentu psikologi konvensional. Dalam pendidikan Islam, perlu dirumuskan tentang dasar-dasar psikologi yang nantinya dijadikan landasan berpikir bagi psikologi pendidikan Islam. Landasan Psikologi yang dipergunakan oleh pendidikan Islam akan mengacu pada rumusan psikologi yang sesuai dengan teologi Islam.

\footnotetext{
${ }_{18}$ Tohirin, Psikologi Pembelajaran Pendidikan Agama Islam (Jakarta: RajaGrafindo Persada, 2008). 11

19 Nana Syaodih Sukmadinata, Pengembangan Kurikulum Teori Dan Praktik (Bandung: Remaja Rosdakarya, 1997). 46
} 
Sebagaimana dijelaskan oleh Nana Syaodih sebelumnya, terdapat dua bidang psikologi yang mendasari pendidikan selama ini, yakni psikologi perkembangan dan psikologi belajar. Dalam Islam perkembangan dan tahap-tahap pertumbuhan manusia telah dijelaskan secara detil, termasuk bagaimana, secara normatif, dijelaskan juga tentang proses pembelajaran sesuai dengan tahap-tahap perkembangan tersebut. Misalnya tentang proses kelahiran anak, yang perlu diazani, tentang bagaimana pembelajaran salat ketika anak belum dan telah baligh, bagaimana pergaulan ketika anak telah baligh, termasuk perlu dan tidaknya wali dalam pernikahan bagi anak perempuan gadis dan janda. Semua itu merupakan contoh kecil dari proses perkembangan yang akan memberikan kontribusi penting dalam psikologi perkembangan dan psikologi belajar dalam pendidikan Islam.

\section{Kesimpulan}

Dari uraian tersebut dapat disimpulkan bahwa salah satu landasan pendidikan adalah psikologi.Pendidikan harus melihat kondisi psikologi individu dalam hal ini adalah peserta didik, utamanya dalam menyusun dan melaksanakan kurikulum sehingga tujuan pendidikan nantinya dapat tercapai secara optimal.

Landasan psikologi diantaranya adalah meliputi psikologi perkembangan, psikologi belajar dan psikologi sosial dan untuk kepentingan pembelajaran.Tinjauan psikologi di atas berimplikasi pada pendidikan dan diharapkan guru sebagai pendidik mampu merencanakan dan menerapkan pendidikan sesuai dengan tahap perkembangan psikologi anak sehingga kemampuan dan potensi anak dapat berkembang seutuhnya.

Adapun dalam pendidikan Islam,psikologi yang dijadikan sebagai acuan adalah psikologi yang berwawasan pada Alquran dan Hadis. Dimana akhirnya menghasilkan output yang berorientasi ketuhanan, insan kamil bahagia di dunia dan akhirat.

\section{Kepustakaan}

Ahmad D. Marimba. Pengantar Filsafat Pendidikan Islam. Bandung: PT. Al-Ma'arif, n.d. Bimo Walgito. Psikologi Sosial (Suatu Pengantar). Yogyakarta: Andi Offset, 2000.

Crow, and Crow. Educational Psikology. America: Barner and Noble Books, 1978.

Danim, and Khairil. Psikologi Pendidikan Dalam Perspektif Baru. Bandung: Alfabeta, 2010. 
Hannna Djumhana Bastaman. Integrasi Psikologi Dengan Islam Menuju Psikologi Islami. Yogyakarta: Pustaka Pelajar, 1997.

Hasan Langgulung. Manusia Dan Pendidikan; Suatu Analisa Psikologi, Falsafah Dan Pendidikan. Jakarta: Pustaka al Husna., 1986.

Jalaluddin Rakhmat. Psikologi Agama, Sebuah Pengantar. Bandung: Mizan, 2003.

M Qurais Shihab. Wawasan Al-Qur'an: Tafsir Maudhu'i Atas Pelbagai Persoalan Umat.

Bandung: Mizan, 1996.

Muhibbin Syah. Psikologi Psikologi Pendidikan Dengan Pendekatan Baru. Bandung: Remaja Rosdakarya, 2003.

Nana Syaodih Sukmadinata. Pengembangan Kurikulum Teori Dan Praktik. Bandung: Remaja Rosdakarya, 1997.

Tohirin. Psikologi Pembelajaran Pendidikan Agama Islam. Jakarta: RajaGrafindo Persada, 2008.

Ulwiyah, Nur. “LANDASAN PSIKOLOGI DAN AKTUALISASINYA DALAM

PENDIDIKAN ISLAM." Religi: Jurnal Studi Islam 6, no. 1 (2015): 76-99.

Zakiah Daradjat. Ilmu Pendidikan Islam. Jakarta: Bumi Aksara, 2006. 